\title{
Why Do They Still Believe that Covid-19 Doesn't Exist? The Challenge of Democracy in Post-Covid in Indonesia
}

\author{
Leni Winarni \\ \{leniwinarni@staff.uns.ac.id\} \\ Universitas Sebelas Maret, Surakarta, Indonesia
}

\begin{abstract}
It has not been a year since the announcement of Joko Widodo and KH. Ma'ruf Amin as the winner of 2019's presidential election, the Covid-19 pandemic has spread worldwide, including Indonesia. The resonance raised fears of the collapse of the economy and other sectors after the outbreak and brought forward a motion not to trust the government to deal with COVID-19. It is natural, in democracy, there are always pro-contra about the policy between those who believe or not in COVID-19. Even though the government policies deal with situations, such as closing places of worship and doing vaccination programs to reduce the victims, some people have rejected it. Using qualitative research methods and theoretical analysis on identity politics initiated by Manuel Castells, this article finds a link between identity politics and compliance against the policy of Covid-19 under Joko Widodo's rule, which was shrouded in excessive religious fanaticism, and resistance to government policies today. However, other indications also show that the government's firmness on public opinion who does not support them is considered a new authoritarian regime to restrict the freedom of speech to those who are antigovernment; this also will encourage resistance.
\end{abstract}

Keywords: resistance identity; government policy; Covid-19

\section{Introduction}

In the 2014 and 2019 elections, where Joko Widodo became the strongest candidate to win, backed by the combined strength of nationalist and religious parties, these are the two elections that have drained public emotions the most since the direct presidential election held in 2004. Three indicators led to this; first, there were only two presidential and vicepresidential candidates in the two elections; second, social networks, that already spread positive, black campaigns, hate speech, and hoaxes related to presidential candidates; and third, the resurgence of Islamic populism dramatically concerning DKI Governor Jakarta Basuki Tjahaya Purnama's blasphemy issue in 2016. However, after the election, polarization because the religious identity politics, especially Muslims, still occurs in society.

Some studies emphasize that not all regions were affected by religious preferences in the 2019 presidential election, it depends on the condition of religious nuance or sociological 
factors rather than the psychology side, which is linked to political parties (Karim 2019; Sirait 2019). While, the others argues that the middle-class Muslim have played an essential role in Islamic identity politics in Indonesia because they are relatively active on social media, educated, and tend to seek religious authority suitable with their educational background and their socio-economic conditions (Damanik 2018; Fata 2019; Jinan 2012). Mutohharun Jinan (2012), finds that today the classification of religious authorities is no longer about institutions but refers to individuals such as kiai, religious teachers, ustadz, habib, and $\mathrm{d} a$ ' $i$. So the traditional religious authority from the ulama previously has shifted in the future because there will be more religious websites or social networks offering solutions for the people, like religious studies, fatwas, even political matters, both with two-way discussions or not.

Instead of examining the debate about shifting religious figures following Muslim's middle-class justifications or the criticize the government's policy, Siti Khodijah Nurul Aula (2020) focuses more on cleric as individual religious authorities who play a role in breaking the Covid-19 chain. She argues if the cleric has three central roles: motivators (reducing the chaos of the people), communicators (sources of information on Covid-19), and idol figures. This role then gives rise to two categories, namely apathetic and accommodative, where the call of followers will automatically follow their attitudes and actions.

Meanwhile, other research supports this argument and concludes that religious leaders affiliated with conventional and anti-mainstream groups also use their influence and justify religious arguments to support or not specific candidates, even leading to a black campaign in the 2019 presidential election (Zuhri, Moh Hidayat Noor, and Miski 2018). The problem is that this phenomenon continues after the presidential election ends, especially community resistance to the COVID-19 management policy in terms of worship. Some researches argue that the cause of the disobedience was because the government was experiencing a crisis of legitimacy, an excessive standard of imagery and rhetoric (Ahmad 2020; Harjudin 2020; Khalik 2020). In contrast, Balqis Mira Firdausy (2020) highlights that the leadership factor was essential during the pandemic, and none of the country leaders could handle it successfully. The other studies argue that the asynchronous between the central and local governments is the main problem why the transmission of Covid-19 still occurs in the community (Putra and Handoko 2021; Sitorus and Rahmadi 2021)

Among all the studies relevant to this paper, the research conducted by Seth Soderborg and Burhanuddin Muhtadi represents how partisan politics determines the level of compliance with Covid-19 policies. Their research in the Jakarta area, shows that the level of compliance is strongly influenced by negative or positive sentiments towards the current regime, which is driven by their choice in the 2019 Presidential Election. Areas that were mass base of Joko Widodo during the 2019 Presidential Election tend to comply with and implement government policies, for example Large-Scale Social Restrictions (PSBP) and vice versa.

These studies above show that religion has a significant role in breaking the chain of the spread of Covid-19 because it involves the masses in their worship rituals (Abbas et al. 2020). Even though the resistance to government policies regarding the regulation of worship during Covid-19 is also based on religious arguments, some religious leaders argue that the policy is a political decision and the government's impartiality towards religion, especially Islam. When viewed from a general perspective, the expression of the freedom to make choices based on religious perspectives or considerations is also part of democracy. The problem is that when a political goal uses religious fanaticism, the meaning could be different. This relevance later became why there were still many people resistant to government policies to deal with Covid19, is there any connection between the political effect after the 2019 Presidential election, 
religious-political identity, and the public compliance under the Joko Widodo government's policies in dealing with Covid-19?

Analyzing all these questions, this research use Manual Castells's (2010) work which divides the identity politics into models: legitimizing identity, the institution built the identity and dominate the social life, while shape the certain identity to a person or group; resistance identity, forcing identity on certain actors causes resistance to create a new identity or identity politics; project identity, social actors create a new identity to achieve some position in society which process to a social movement that can change the whole of social structure. Castells believes many elements construct the identity, such as history, geography, biology, collective memories, power, institution, and religious perspective. Thus, in the age of information nowadays, not only create the network societies, but also influence the alter in many sectors, for example, politics, culture, and economics in society. Identity is about how individually identified themselves and the dominant group labels the other's identity (Castells 2010). However, the internal and external factor could create identity in the society.

This research focuses on such questions; therefore, this work proposes the following proposition: first, the finding and analysis that presents the revival of Islam politics during the 2019 presidential election and demonstrate the relevance between the political support during the election, besides comparing it with the others religion to see this contestation, discussion the link between the disobedience the policy during the pandemic Covid-19 against the policy, 2019 presidential election, political situation, and the role of religious leaders; the second section provides discussion and conclusion.

\section{Result and Discussion}

\subsection{Politics and Religion in 2019 Presidential Election}

In fact, the emergence of Islamic political identity is not a new phenomenon in Indonesia, even the situation occurred at the beginning of independence. Although the politic of containment was implemented in the Suharto era (Darwis, Putra, and Cangara 2020), the antimainstream Islamic groups still tried to spread the ideology exclusively within their communities and clandestinely. This constructs the prejudice that Islam is not compatible with the policy under Soeharto's regime and vice versa. However, after the end of the Suharto regime in 1998, the euphoria of democracy also affected various ideologies in Indonesia. Thus Indonesia enters the era of liberal democracy (Thohari 2019). Of course, the development of information technology influences the spread of anti-mainstream religious ideology with their political agenda on social media, which targets the youth. In various presidential elections, the use of the Internet to conduct effective and efficient campaigns has dramatically increased since the 2014 election. This also applies to use the internet for tearing down the political competitor both from the professional or sympathizer to support their candidate through the black campaign and spread the hoaxes. These strategies dominate the current politic in almost the campaign season. Based on data from the Ministry of Communication and Information, from August 2018 to March 2019, there were 1,224 hoaxes, 630 of which contained political hoaxes (Anon 2020).

The relationship between political choices during the presidential election and it is necessary to review the political map in Indonesia by comparing the results of the 1955 election, presidential election in 2014 and 2019. This might impress that Joko Widodo represents the nationalist and moderate Islam, while Prabowo Subianto represents 
conservative Islam, although only supported by two Islamic parties, Partai Amanat Nasional (PAN, National Mandate Party) and Partai Keadilan Sosial (PKS, Social Welfare Party). While Joko Widodo was supported by Partai Kebangkitan Bangsa (PKB, National Revival Party), Partai Persatuan Pembangunan (PPP, Development Union Party), Partai Bulan Bintang (PBB, Star Moon Party) (see table 1 and 2). The tables show a relationship between regions with high religious roots that support the presidential candidates supported by religious parties, especially Islam. This difference with the Central Java region is that the political gestures represent the nationalist. At the same time, east Java is the basis mass of Islam moderate, and the minority groups in the east region choose the nationalist parties.

Despite, if they do not support the elected president, it is still debatable whether they will support the policy of Covid-19 or not. Of course, this requires data, facts, and a longer research duration to prove this assumption. For example, according to the results of Satgas Covid-19 monitoring of community compliance with health protocols during the Eid holiday (May 12-15, 2021), it shows that Jakarta has the level lowest compliance in the use of masks with $27 \%$, followed by Bangka Belitung with $33 \%$, Riau with 58\% and South Sumatra with $62 \%$ (Jppn.com 2021). Meanwhile, the lowest adherence to wearing masks was in Bangka Belitung at 33\%, South Sumatra at 58\%, and Jakarta at 60\% (Jppn.com 2021).

These data certainly do not generalize that the level of compliance reflects the community's political identity during the 2019 presidential election. However, at least this can illustrate a pattern of political history that repeatedly shows that identity politics is not a process that happens but because of political views that are both cultural and religious.

\subsection{How Religious Political Identity Contribute to the Resistance and Accepting the Policy of Covid-19?}

This kind of rhetoric question often appears on social media of why we need to comply with the state policy if the president is not our choice in the presidential election, even sometimes supported with a religious perspective. This situation is certainly not beneficial for the government to implement policies to effectively break the chain of the spread of Covid-19 in society. Some of them take advantage of this pandemic condition by provoking the society that all the policies regarding the rule of religious activity are the politicization against God and religion itself. On the one hand, political elites and observers criticize the government's policies to handle the pandemic have not managed optimally. For example, the president of the Regional Institute of Autonomy, Djohermansyah Djohan, evaluated Pembatasan Sosial Berskala Besar (PSBB, the Great Social Limitation) was not effective in the management and control of Covid-19. According to him, the government seems unwilling to listen to the local government's proposals to deal with the corona virus pandemic (Maharani and Erdianto 2020). While public policy observer Agus Pambagio said, this condition is also the cause of the increasingly widespread Covid-19 in Indonesia. Agus also mentioned that weak enforcement rules made the strict PSBB or Pemberlakuan Pembatasan Kegiatan Masyarakat (PPKM, Enforcement of Restrictions on Community Activities) has no different (CNBC 2021). Many public opinions on government policies have turned into a never-ending debate as the pandemic continues. Neither the government nor the public benefit from this situation.

On the other hand, government policies often intersect with religious activities, which will automatically respond by religious leaders, both those who sit in organizational and cultural structures. Those who are elite groups of moderate organizations tend to provide understanding to the public through the media openly and at the same time represent the attitudes of their groups, such as Muhammadiyah and NU. In a separate interview, the 
chairman of the NU Cares for Covid-19 Task Force, Muhammad Makky Zamzani, said that the bahtsul masail forum had discussed the issue of rejection of corpses, the stigma of people with Covid-19, and religious activities during Ramadan (Firmansyah 2020). Meanwhile, MCCC PP (Muhammadiyah Covid-19 Command Center) Vice Chairmain for Cooperation and Promotion Muhammadiyah, Corona Rintawan said the Pimpinan Pusat (PP, Central Leadership) Muhammadiyah had issued a circular letter implemented by management to the lowest level (Firmansyah 2020). The two most prominent Islamic organizations agreed to take a persuasive approach to implement health protocols, especially for their members, then the community.

Among the religions in Indonesia, Islam is the majority, and often, Islamic religious leaders also have different views on Covid-19 than other religious groups. Nevertheless, the religious cluster which contributed to the Covid-19 outbreak is not only from Islam. Doni Monardo, Chair of Satgas Covid-19 (Satuan Tugas, the Task Force of Covid-19, 2019-2021), said that at the beginning of Covid-19, the cluster from religious activities was one of the most significant contributors to growing the number of Covid-19 outbreaks (DetikNews 2021a). The Head of the Data and Technology Division Satgas Covid-19, Dewi Nur Aisyah, said that religious activities significantly increased the number of cases because religious events usually involved mass gatherings (see table 1.3) (Iskana 2020). They also mentioned 25 clusters of Covid-19 related to worship in Jakarta: 7 clusters from tahlilan/takziah with 69 cases; 6 clusters from worship activities in mosque with 126 cases; 4 clusters from worship in church with 41 cases; 4 clusters from pastor's dom with 155 cases; and 4 clusters from Islamic boarding school with total cases 395 people with Covid-19 (Bayu 2020).

The explosion of Covid-19 cases that hit Indonesia around June 2021 was also related to religious activity, mudik, Indonesian tradition of returning to hometowns before the religious celebration, including for Muslims ahead of Eid al-Fitr. Alexander K. Ginting, the Head of the Handling Division of Satgas Covid-19, conveys this current situation. He stated that the recent coronavirus cases were due to the mobilization of 1.5 million pemudik (travelers), even though the government had banned this activity, and the other reason is the arrival of Tenaga Kerja Indonesia (TKI, Indonesian workers) from abroad (CNN Indonesia 2021). Otherwise, according to the Deputy Chairperson of the Ikatan Dokter Indonesia (IDI, Indonesian Doctors Association), Slamet Budiarto says that mudik is not the leading cause of the explosion of the Delta variant of Covid-19 cases in Indonesia. However, the leading cause is the entry of foreign delta viruses, both brought by foreigners or Indonesians who work there. In other words, the government does not apply strict rules regarding the supervision of people entering and leaving Indonesia (DetikNews 2021b).

These data show that religious activities make a significant contribution to the transmission of Covid-19 in Indonesia. However, this attitude should be understanding from the identity aspects regarding the influence of the religious authorities based on the Mutoharun Jinan research. According to his classification, religious leaders play an important role because they generally exist in social media that can reach all social classes, whether they support government policies or not. At this point, the government clearly labeled moderate to some religious authorities such as MUI, Muhammadiyah, and NU because, from the government's perspective, they will be in line with government policies to reduce the impact of the pandemic. But it has gone through a long process because in the earlier period, especially during the Soeharto era, both Muhammadiyah and NU were also mentioning as radical organizations. it must be stressed, even though they give support to the government, they are also often critical of the policy if it unsuitable with the religion and does not provide maslahat (benefits). 
K.H. Said Aqil Siradj, the Chairmain of Pengurus Besar Nahdlatul Ulama (PBNU, Executive Board of Nahdlatul Ulama), said that there are some kiai (ulema) who still do not believe in covid and vaccines (Saputro et al. 2021). They even think that the vaccine is a killing mass weapon. He worries that people will assume that Islam, especially the religious leaders of the NU, is irrational and that Islam is against science in the future. Among some religious leaders who declare not to support Joko Widodo in the presidential election at once are also said to the public that he does not believe in Covid-19 is controversial Ustazd Yahya Waloni. He even ever has reported by Joko Widodo's Success Team to the police because of hate speech case after attacking the personal side to the vice-presidential candidates, such as KH Ma'ruf Amin, West Nusa Tenggara Governor, Tuan Guru Bajang Muhammad Zainul Majdi, and The leader of Partai Demokrasi Indonesia Perjuangan (PDIP, Indonesian Democracy Struggle Parties), Megawati Soekarnoputri (Siddiq and Widiatuti 2018). Under Joko Widodo's rule, he uploads anti-Covid 19 statements and negative sentiment to the government. Despite this, only a few religious leaders have the same thoughts as Ustadz Yahya Waloni and brought the narrative on Covid-19 are conspiracy, soldiers of God, et cetera, compared the moderate one, but they narratives about religious figures and their views on Covid-19 affect their followers and society (Irfani 2021). The arguments of those who do not believe in COVID-19 are very dangerous and harmful to society. Both the government and anti-political opposition have a mass of fanatical supporters. While the other anti-mainstream Islamic organization, such as those affiliated with Front Pembela Islam (FPI, Front Islamic Defender), led by Habib Rizieq Shihab, choose to neglect the government policy about health protocol and still organize their activities. This organization was banned by the government last year, December 12, 2020.

According to the Indonesian Political Indicators (IPI) survey from February 1-3, 2021, it shows that out of 1,200 respondents, 21.2 percent or one-fifth consider Covid-19 to be a hoax (Lubis 2021).On the other hand, the survey institute The Center for Strategic and International Studies (CSIS) conducted a survey on COVID-19 and vaccines for 400 respondents each in Jakarta and Yogyakarta, said that Generation Z, young people aged 17 to 22, is the group that most distrusts Covid-19 and does not believe in vaccines (Lubis 2021). The survey uses a random sampling method, and the sample margin of error is approximately 3.46 percent. Survey results show that around 10 percent of respondents in DKI Jakarta and 6.3 percent of respondents in Yogyakarta do not believe in covid-19

Referring to the data, facts, and explanations above, the narrative constructed by the antimainstream religious leaders shows their existence using a different paradigm than other moderate religious leaders who generally have good relations with the authorities; besides, considered as an opportunist. They show a new identity as social resistance and a symbol against the regime that is narrated not stand for the people. Indeed, the heroic narratives against the regime with religious justification as people's consolation who feel unjust because of the limited access to resources. While the government constructs that those who oppose government policies by politicizing religion have sown the seeds of intolerance to radicalism by violently criticizing them without evidence or facts, on the other hand, they believe that the government has criminalized the ulama.

\section{Conclusion}

At the partisan, the relevance between the different political choices in the presidential election and the policy resistance under government today might occur. Moreover, if the 
narratives are always preserved because they support religious leaders, especially religious figures who have the same justification. This behavior also grows more robust when the figures who become its role models address the failure or indolence of the regime in dealing with Covid-19 as political material to defeat the regime on religious grounds. These antimainstream groups are also generally disappointed in the regime or dissatisfied because it does not align with their idealistic views and political agenda. For example, they feel that the current government does not reflect an Islamic government and is too liberal. These unpleasant speeches towards the government met with the people's disappointment, thus becoming a new form of identity and social resistance to power. They who become target are those who lack knowledge and do not understand the history of local politics and are well educated, mainly the young people.

The government needs the cooperation of all parties to face and deal with the pandemic crisis, not find a great escape from Covid-19. This crisis can trigger two things: first, all components of the nation work together to overcome the crisis; and second, otherwise, those who previously did not make their choice to the current regime in the presidential election become more resistant and kept the political distance and polarization. In other words, They imagine, if the current government did not win, maybe handling Covid-19 would be better. Government supporters will certainly not agree with this argument. The pro and contra of this Covid-19 policy have even often become an arena of contention on social media between those who used to support Joko Widodo and those who did not, which often use their own or their community's religious views. The problem is not in the context of religion but the narrative of religious politicization, the role of religious leaders, opposition elites, is also a part of the dynamic of democracy in the middle of the crisis, where the society still facing the reality of the pandemic that has an impact on almost all aspects of life.

Table 1. 1955 Election

\begin{tabular}{|c|c|c|c|c|c|c|c|c|c|}
\hline \multirow[b]{2}{*}{ Region } & \multicolumn{9}{|c|}{$\begin{array}{l}\text { Political Party } \\
\end{array}$} \\
\hline & Masyumi & PNI & Parkindo & PKI & Perti & PPTI & PSII & $\begin{array}{l}\text { Nahdlatul } \\
\text { Ulama } \\
\text { (NU) }\end{array}$ & $\begin{array}{c}\text { Chatolic } \\
\text { Party }\end{array}$ \\
\hline $\begin{array}{l}\text { North } \\
\text { Sumatra }\end{array}$ & & & & & & & & & \\
\hline & $37 \%$ & $15.44 \%$ & $13.65 \%$ & $12.13 \%$ & & & & & \\
\hline Central & & & & & & & & & \\
\hline $\begin{array}{l}\text { Sumatra } \\
\text { (Including } \\
\text { West }\end{array}$ & $50.77 \%$ & & & $5.76 \%$ & $22.38 \%$ & $2.25 \%$ & & & \\
\hline Sumatra) & & & & & & & & & \\
\hline $\begin{array}{l}\text { South } \\
\text { Sumatra }\end{array}$ & $43.23 \%$ & $14.67 \%$ & & $12.14 \%$ & & & $10.24 \%$ & & \\
\hline West Java & $26.47 \%$ & $22.21 \%$ & & $10.84 \%$ & & & & $9.66 \%$ & \\
\hline East Java & $11.24 \%$ & $22.79 \%$ & & $23.28 \%$ & & & & $34.13 \%$ & \\
\hline $\begin{array}{l}\text { Central } \\
\text { Java }\end{array}$ & $10.02 \%$ & $33.54 \%$ & & $25.85 \%$ & & & & & \\
\hline $\begin{array}{l}\text { East Nusa } \\
\text { Tenggara }\end{array}$ & $14.66 \%$ & $5.79 \%$ & $18.13 \%$ & & & & & & $40.98 \%$ \\
\hline
\end{tabular}

Table 2. 2014 dan 2019 Presidential Election

\begin{tabular}{lcccc}
\hline \multirow{2}{*}{ Region } & \multicolumn{2}{c}{$\mathbf{2 0 1 4}$} & \multicolumn{2}{c}{$\mathbf{2 0 1 9}$} \\
\cline { 2 - 5 } & $\begin{array}{c}\text { Joko Widodo- } \\
\text { Jusuf Kalla }\end{array}$ & $\begin{array}{c}\text { Prabowo Subianto- } \\
\text { Hatta Rajasa }\end{array}$ & $\begin{array}{c}\text { Joko Widodo-K.H. } \\
\text { Ma'ruf Amin }\end{array}$ & $\begin{array}{c}\text { Probowo Subianto- } \\
\text { Sandiago Uno }\end{array}$ \\
\hline Aceh & $45.61 \%$ & $54.39 \%$ & $15.01 \%$ & $84.99 \%$ \\
West Sumatra & $23.08 \%$ & $76.92 \%$ & $15.88 \%$ & $84.12 \%$ \\
South Sumatra & $48.74 \%$ & $51.26 \%$ & $38.83 \%$ & $61.16 \%$ \\
\hline
\end{tabular}




\begin{tabular}{|c|c|c|c|c|}
\hline West Java & $40.22 \%$ & $59.78 \%$ & $39.37 \%$ & $60.63 \%$ \\
\hline Central Java & $66.65 \%$ & $33.35 \%$ & $77.02 \%$ & $22.98 \%$ \\
\hline East Java & $53.17 \%$ & $46.9 \%$ & $65.7 \%$ & $34.21 \%$ \\
\hline East Nusa Tenggara & $65.92 \%$ & $34.08 \%$ & $77.02 \%$ & $22.98 \%$ \\
\hline
\end{tabular}

Source: (DetikNews 2019) (CNN Indonesia 2019)

Table 3. List of Religious Cluster of Covid-19

\begin{tabular}{|c|c|c|c|}
\hline $\begin{array}{l}\text { Religious } \\
\text { Activities }\end{array}$ & Date & Region & $\begin{array}{l}\text { The Number of } \\
\text { Covid-19 Cases }\end{array}$ \\
\hline Worship, GIPB Sinode & February 2020 & Bogor, West Java & 24 \\
\hline Seminar without riba & February, 2020 & Bogor, West Java & 24 \\
\hline Worship, Bethel church & March, 2020 & Lembang, West Java & 226 \\
\hline $\begin{array}{l}\text { World's Ijtima Ulama. } \\
\text { Asian zone }\end{array}$ & $\begin{array}{l}\text { 8-29 March, } \\
2021\end{array}$ & Goa, South Sulawesi & 1.248 \\
\hline $\begin{array}{l}\text { Temboro boarding } \\
\text { school }\end{array}$ & Mei, 2020 & Magetan, East Java & 193 \\
\hline $\begin{array}{l}\text { Worship, Jemaah } \\
\text { Tabligh Akbar }\end{array}$ & Mei, 2020 & $\begin{array}{l}\text { Gunung Kidul, } \\
\text { Yogyakarta }\end{array}$ & 18 \\
\hline $\begin{array}{l}\text { Worship, Jemaah } \\
\text { Tabligh Akbar }\end{array}$ & Mei, 2020 & Sleman, Yogyakarta & 24 \\
\hline Worship, GPIB & Mei, 2020 & Sleman, Yogyakarta & 17 \\
\hline $\begin{array}{l}\text { FPI } \\
\text { Maulid Nabi }\end{array}$ & $\begin{array}{l}\text { November, } \\
2020\end{array}$ & $\begin{array}{l}\text { Megamendung, West } \\
\text { Java }\end{array}$ & 80 \\
\hline
\end{tabular}

\section{References}

[1] Abbas, Ahmed M., Ebrahim Yousof, Shimaa Selim, Safaa Ahmed, and Yasmin Ismail. 2020. "COVID-19: How Does Religion Interact with Pandemic?" Archives of Health Science 4(September):1-2. doi: 10.31829/2641-7456/ahs2020-4(1)-132.

[2] Ahmad, Nyarwi. 2020. "Presidential Rhetoric in the Covid-19 Pandemic Era: Jokowi's Aristotelian Rhetorical Leadership Models Before and After Implementation of Lock Down Policy.” Jurnal Komunikasi Ikatan Sarjana Komunikasi Indonesia 6(1):72-85. doi: http://dx.doi.org/10.25008/jkiski.v6i1.538 Nyarwi.

[3] Aula, Siti Khodijah Nurul. 2020. "Peran Tokoh Agama Dalam Memutus Rantai Pandemi Covid-19 Di Media Online Indonesia." Living Islam: Journal of Islamic Discourses 3(1):125. doi: 10.14421/lijid.v3i1.2224.

[4] Damanik, Erond Litno. 2018. "Hashtag \#2019GantiPresiden: Sentimen Anti-Petahana Dan Orientasi Politik Pemilih Pemula Menghadapi Pilpres 2019 Di Pematangsiantar." JPPUMA Jurnal Ilmu Pemerintahan Dan Sosial Politik Universitas Medan Area 6(2):166-76. doi: 10.31289/jppuma.v6i2.1996.

[5] Darwis, Bama Andika Putra, and Abdul Razaq Cangara. 2020. "Navigating through Domestic Impediments: Suharto and Indonesia's Leadership in ASEAN.” International Journal of Innovation, Creativity and Change 13(6):808-24. doi: 10.5281/zenodo.4412041.

[6] Fata, Mohamad Khoirul. 2019. "Membaca Polarisasi Santri Dalam Kontestasi Pilpres 2019." 18(November 2018):325-44. doi: https://doi.org/10.21274/dinamika.2018.18.2.325-346. 
[7] Firdausy, Balqis Mira. 2020. “Menakar Kualitas Kepemimpinan Presiden Jokowi Di Tengah Wabah Pandemi COVID-19.'” Journal of Chemical Information and Modeling 53(9):1689-99.

[8] Harjudin, Laode Ode. 2020. "Dilema Penanganan Covid-19: Antara Legitimasi Pemerintah Dan Kepatuhan Masyarakat.” Jurnal Kesejahteraan Dan Pelayanan Sosial 1(1):90. doi: 10.52423/jkps.v1i1.13249.

[9] Irfani, Faisal. 2021. "Menyelami Isi Pikiran Penganut Konspirasi Anti-COVID \& AntiVaksin." Tirto.Id. Retrieved (https://irto.id/menyelami-isi-pikiran-penganutkonspirasi-anti-covid-anti-vaksin-gapS).

[10] Jinan, Mutohharun. 2012. "New Media Dan Pergeseran Otoritas Keagamaan Islam Di Indonesia." Jurnal Lektur Keagamaan 10(1):181-208. doi: https://doi.org/10.31291/jlk.v10i1.178.

[11] Karim, Abdul Gaffar. 2019. "Mengelola Polarisasi Politik Dalam Sirkulasi Kekuasaan Di Indonesia: Catatan Bagi Agenda Riset.” Politika: Jurnal Ilmu Politik 10(2):215-28. doi: 10.14710/politika.10.2.2019.200-210.

[12] Khalik, Subehan. 2020. "Cerminan Legitimasi Pemerintahan Islam Di Masa Pandemi." Al-Risalah Jurnal Ilmu Syariah Dan Hukum 20(1):1-15. doi: 10.24252/alrisalah.v20i1.15328.

[13] Putra, Ardi, and Tito Handoko. 2021. "Komunikasi Pemerintah Pusat Dan Pemerintah Daerah: Kasus Dinamika Pelaksanaan Local Lockdown Dalam Mencegah Penyebaran COVID-19." Jurnal Administrasi Politik Dan Sosial 2(1):1-15. doi: 10.46730/japs.v2i1.40.

[14] Sirait, Ferdinand Eskol Tiar. 2019. "Ujaran Kebencian, Hoax, Dan Perilaku Memilih (Studi Kasus Pada Pemilih Presiden 2019 Di Indonesia).” Jurnal Penelitian Politik (LIPI) 16(1):111-124.

[15] Sitorus, Amalia Azmi, and Muhammad Firdaus Rahmadi. 2021. "Disinkronisasi Kebijakan Pemerintah Indonesia Dalam Penanganan COVID-19.” Jurnal Renaissance 6(1):721-32.

[16] Zuhri, Saifuddin, Moh Hidayat Noor, and Miski. 2018. "Komunitas Online Www.Arrahmah.Com Serta Seruan Kembali Pada Al-Quran Dan Hadis Identitas, Ideologi, Dan Imaji Fundamentalisme." Pp. 144-60 in Ancoms: 2nd Annual Conference for Muslism Sholars.

[17] Castells, Manuel. 2010. The Power of Identity, The Information Age: Economy, Society, and Culture Volune II. Vol. 49. Blackwell Publishing Ltd.

[18] Maharani, Tsarina, and Kristian Erdianto. 2020. "Pengamat: Kebijakan PSBB Belum Tegas, Tak Efektif Atasi Covid-19.” Kompas.Com.

[19] Saputro, Febrianto Adi, Muhyiddin, Fauziah Mursid, and Ronggo Astungkoro. 2021. "Masih Ada Kyai Tak Percaya Covid Kala Ratusan Ulama Wafat." Republika.Co.Id.

[20] Siddiq, Taufiq, and Rina Widiatuti. 2018. "PKB Laporkan Yahya Waloni Ke Bareskrim Terkait Ujaran Kebencian." Nasional.Tempo.Co.

[21] Thohari, Hajriyanto Y. 2019. "Demokrasi Atau Demosyurakrasi_ - Suara Muhammadiyah." Suara Muhammadiyah.

[22] Anon. 2020. "Peta Sebaran Covid-19 Di Indonesia Menginfeksi 17 Provinsi, Terbanyak Di DKI Jakarta." Tribunnews.

[23] Bayu, Dimas Jarot. 2020. "25 Klaster Corona Muncul Akibat Kegiatan Agama Di Jakarta." Databoks.Katadata.Co.Id. Retrieved (https://databoks.katadata.co.id/datapublish/2020/11/27/25-klaster-corona-munculakibat-kegiatan-agama-di-jakarta). 
[24] CNN Indonesia. 2019. "Infografis Peta Kekuatan Jokowi Prabowo Di Pemilu 2014." Cnnindonesia.Com.

[25] CNN Indonesia. 2021. "Satgas Sebut Pemudik Dan TKI Penyebab Lonjakan Kasus Covid-19." CNN Indonesia. Retrieved (https://www.cnnindonesia.com/nasional/20210701195013-20-662031/satgas-sebutpemudik-dan-tki-penyebab-lonjakan-kasus-covid-19).

[26] CNBC. 2021. "Penegakan Aturan Lemah, PPKM DInilai Tak Efektif." CNBC Indonesia.

[27] DetikNews. 2019. "Infografis Peta Kemenangan Jokowi Di Pilpres 2019.” Detik.Com. Retrivied https://news.detik.com/infografis/d-4558410/infografis-peta-kemenanganjokowi-di-pilpres-2019

[28] DetikNews. 2021a. "Doni_Awal Mula Kasus COVID Terbanyak Klaster Keagamaan, Sekarang Keluarga." Detik.Com. Retrieved (https://news.detik.com/berita/d5324323/doni-awal-mula-kasus-covid-terbanyak-klaster-keagamaan-sekarangkeluarga).

[29] DetikNews. 2021b. "IDI Ungkap Penyebab Utama Kasus Corona Naik Bukan Mudik, Tapi Varian Delta.” Detiknews. Retrivied https://news.detik.com/berita/d-5622707/idiungkap-penyebab-utama-kasus-corona-naik-bukan-mudik-tapi-varian-delta

[30] DetikNews. 2019. "Infografis Peta Kemenangan Jokowi Di Pilpres 2019." Detik.Com.

[31] DetikNews. 2021a. "Doni_Awal Mula Kasus COVID Terbanyak Klaster Keagamaan, Sekarang Keluarga." Detik.Com. Retrieved (https://news.detik.com/berita/d5324323/doni-awal-mula-kasus-covid-terbanyak-klaster-keagamaan-sekarangkeluarga).

[32] DetikNews. 2021b. "IDI Ungkap Penyebab Utama Kasus Corona Naik Bukan Mudik, Tapi Varian Delta." Detiknews.

[33] Firmansyah, Manda. 2020. "Larang Kegiatan Di Masjid, NU Dan Muhammadiyah: Beri Edukasi." Alenia.Id. Retrieved April 1, 2021 (https://www.alinea.id/nasional/larang-kegiatan-di-masjid-nu-dan-muhammadiyahberi-edukasi-b1ZMY9usf).

[34] Hamdi, Imam, and Jobpie Sugiharto. 2020. "Maulid Nabi Di Markas FPI, Megawati Dan Jokowi Didoakan Umurnya Pendek - Nasional Tempo.” Nasional.Kontan.Co.Id.

[35] Irfani, Faisal. 2021. "Menyelami Isi Pikiran Penganut Konspirasi Anti-COVID \& AntiVaksin." Tirto.Id. Retrieved (https://tirto.id/menyelami-isi-pikiran-penganutkonspirasi-anti-covid-anti-vaksin-gapS).

[36] Iskana, Febrina Ratna. 2020. "Sejumlah Kegiatan Agama Munculkan Klaster Baru Covid-19 Di RI." Https://Katadata.Co.Id/. Retrieved (https://katadata.co.id/febrinaiskana/berita/5fbe329c443d9/sejumlah-kegiatan-agamamunculkan-klaster-baru-covid-19-di-ri).

[37] Jppn.com. 2021. "Satgas Covid-19 Sayangkan Tingkat Kepatuhan Warga DKI Rendah Untuk Patuhi Protokol Kesehatan - Nasional JPNN." Jppn.Com.

[38] Liputan 6. 2020. "Klaster Temboro." Liputan6.Com. Retrieved (https://www.liputan6.com/tag/banjir).

[39] Lubis, Zainuddin. 2021. "Selain Dokter Lois Owien, Sebagian Penceramah Agama Juga Tak Percaya Covid-19_Bincang Syariah.” Bincangsyariah.Com.

[40] Sabandar, and Switzy. 2020. "3 Klaster Besar Corona Covid-19 Di DI Yogyakarta Berasal Dari Acara Keagamaan, Cek Detailnya.” Liputan6.Com. Retrieved April 1, 2021 (https://www.liputan6.com/regional/read/4243284/3-klaster-besar-corona-covid19-di-di-yogyakarta-berasal-dari-acara-keagamaan-cek-detailnya). 
[41] Teguh, Irfan. 2019. "Ekspresi Politik Indonesia 2019: Kembali Seperti Pemilu 1955?" Tirto.Id. 